\title{
A Rare Cause of Pulmonary Embolism in Children: Use of Risperidone
}

\author{
Çocuklarda Pulmoner Embolizmin Nadir Bir Nedeni: Risperidon
}

\author{
(1) Merve Koç Yekedüz ${ }^{1}$, (1) Tanıl Kendirli22, (1) Ebru Azapağası², (1) Nazan Çobanoğlu3 \\ ${ }^{1}$ Ankara University Faculty of Medicine, Department of Pediatric Metabolism, Ankara, Turkey \\ ${ }^{2}$ Ankara University Faculty of Medicine, Department of Pediatric Intensive Care, Ankara, Turkey \\ ${ }^{3}$ Ankara University Faculty of Medicine, Department of Pediatric Pulmonology, Ankara, Turkey
}

\section{Abstract}

Pulmonary embolism is a very rare clinical picture in the pediatric age group known to be healthy and usually develops in the presence of at least one risk factor (immobility, hypovolemia, malignancy, trauma, hereditary thrombotic disorders, etc). Risperidone is a relatively safe antipsychotic drug. Pulmonary embolism (PE) is not a common and well-known side effect of risperidone in children.

In this case report, a 17.5-year-old male patient presented with abdominal pain, fever and respiratory distress to the pediatric emergency department and was diagnosed with pulmonary embolism after radiological examinations. It is thought to be a rare adverse effect due to risperidone treatment, in which the patient has no known classical risk factors for thromboembolism and all thrombophilia tests are normal.

Up to the present, a case of PE development due to the use of risperidone in pediatric patients has been reported in the literature. There are no cases in the literature, of adolescents developing PE due to the use of risperidone without an underlying risk factor.

Keywords: Pulmonary embolism, risperidone, risk factors, adverse effect, adolescent

\section{Öz}

Pulmoner embolizm sağlıklı olduğu bilinen çocuk yaş grubunda oldukça nadir klinik bir durumdur. Genellikle en az bir risk faktörü (hareketsizlik, hipovolemi, malignite, travma, kalıtsal trombotik bozukluklar, vb.) varlığında gelişir. Risperidon, nispeten güvenli bir antipsikotik ilaçtır. Pulmoner embolizm (PE), çocuklarda risperidonun yaygın ve iyi bilinen bir yan etkisi değildir.

Bu olgu sunumunda, çocuk acil servise karın ağrısı, ateş ve solunum sıkıntısı ile başvuran ve radyolojik tetkiklerden sonra pulmoner emboli tanısı konan 17,5 yaşında bir erkek hasta sunulmuştur. Hastanın tromboembolizm için bilinen klasik risk faktörleri bulunmaması ve tüm trombofili testlerinin normal olması sebebi ile risperidon tedavisine bağlı nadir bir yan etki olarak PE geliştiği düşünülmektedir. Günümüze kadar çocuk hastalarda risperidon kullanımına bağlı bir PE gelişimi olgusu literatürde bildirilmiştir. Literatürde, altta yatan bir risk faktörü olmayan risperidon kullanımı nedeniyle PE gelişen ergen olgu yoktur.

Anahtar Kelimeler: Pulmoner embolizm, risperidon, risk faktörleri, yan etki, ergen

\section{Introduction}

Pulmonary embolism (PE) is a rare clinical picture in childhood. $P E$ in children is often not diagnosed. The incidence was reported as $0.4-2.2 / 100.000$ in children under 15 years of age. ${ }^{1,2}$ This rate increases to $3.7 \%$ with autopsy studies done on children. ${ }^{3.5}$ Awareness of pediatricians should be increased because PE is much less common in children than in adults.
Diagnosis of PE in children, which is easier to diagnose today due to increased diagnostic tests, is life-saving. The first condition for the diagnosis of this life-threatening condition is the suspicion of the pediatrician.

Venous thromboembolism may be due to trauma, febrile disease, genetic predisposition and drug use. Venous thromboembolism due to antipsychotic drugs is a rare side effect of the drug that causes PE. ${ }^{6}$

Yazışma Adresi/Address for Correspondence: Merve Koç Yekedüz, Ankara University Faculty of Medicine, Department of Pediatric Metabolism, Ankara, Turkey E-posta: drmervekoc13@hotmail.com ORCID ID: orcid.org/0000-0003-0637-417X

Geliş Tarihi/Received: 12.06.2018 Kabul Tarihi/Accepted: 18.07.2019

-Telif Hakkı 2020 çocuk Acil Tıp ve Yoğun Bakım Derneği

Çocuk Acil ve Yoğun Bakım Dergisi, Galenos Yayınevi tarafından yayınlanmıstıı. 
Risperidone is an atypical antipsychotic that antagonizes serotonin and dopamine receptors. ${ }^{6}$ Studies have shown that risperidone is a relatively safe drug, but cases of pulmonary thromboembolism due to risperidone are rarely described in the literature. ${ }^{1,6-8}$

Here, we present an adolescent case of pulmonary thromboembolism due to the use of risperidone.

\section{Case Report}

A 17-year-old male patient without a known illness in his background until two months ago was started with risperidone (4 mg/day), valproic acid (50 mg/kg/day), quetiapine (25 $\mathrm{mg} /$ day) by child psychiatry due to findings consistent with psychosis. The patient presented with abdominal pain, fever and respiratory distress to the pediatric emergency department.

We learned that the patient's complaint started four days before the history and in another hospital where the patient was admitted for the same complaints, pneumonia was considered and oral amoxicillin clavulanic acid treatment was started but due to continued complaints, it was considered as acute appendicitis. The patient was referred to our hospital afterwards.

The patient was agitated and uneasy when he applied to the hospital. The patient had severe abdominal pain and respiratory distress but he had no leg edema, leg pain, signs of Homans. His rectal temperature was $37{ }^{\circ} \mathrm{C}$, respiratory rate was $30 / \mathrm{min}$, heart rate was $88 / \mathrm{min}$, blood pressure was $110 / 80 \mathrm{mmHg}$ and oxygen saturation was $90 \%$ with pulse oximeter (when not receiving oxygen support). Abdominal examination showed serious tenderness and defensive findings on the right upper quadrant. His respiratory sounds were decreased at the lower zone of the right lung.

The patient had no history of travel, trauma, febrile illness, rheumatologic disease and no family history of thromboembolism.

In the complete blood count, the white blood cell was $18.400 / \mathrm{mm}^{3}$, hemoglobin was $12.3 \mathrm{gr} / \mathrm{dL}$, and the platelet was $149,000 / \mathrm{mm}^{3}$. According to liver and kidney function tests, blood electrolytes were normal. Coagulation parameters (prothrombin time $14.5 \mathrm{sec}$, activated partial thromboplastin time $30.8 \mathrm{sec}$ ) were not clinically significant. The blood gas $\left(\mathrm{pH} 7.39, \mathrm{pCO}_{2} 37.5, \mathrm{pO}_{2} 55.6 \mathrm{HCO}_{3} 22.6\right.$ base excess -1.6) was normal. D-dimer was found to be high at $796 \mathrm{ng} / \mathrm{mL}$ (0-243) and C-reactive protein at $358.9 \mathrm{mg} / \mathrm{L}(\mathrm{N}: 0-5 \mathrm{mg} / \mathrm{L})$.

Posteroanterior chest X-ray showed bilateral paracardiac infiltrations and infiltrations at the right base. Electrocardiogram showed no pathological findings. Abdominal ultrasonography (USG) was not performed because the abdominal pain of the patient was very severe and supine position could not be sustained. Causes of abdominal pain could not be evaluated by USG. Abdomino-thoracic computed tomography (CT) angiography was recommended by pediatric radiology so as not to overlook the causes of acute abdomen, but also diagnose acute respiratory distress causes such as pulmonary thromboembolism. Abdomino-thoracic CT angiography was performed. CT showed consolidation including frosted glass densities at the posterobasal in the lower lobe of the right lung, central filling defect in the pulmonary artery branches and segmental branches of the lower lobe of the right lung, similar findings in the pulmonary artery branches of the lower lobe of the left lung, sub-segmentary atelectatic densities in the right lower lobe and pleural effusion in the right (Figure 1). Tomography was reviewed by pediatric pulmonary disease, pediatric intensive care, and pediatric radiology specialists. Filling defects of arteries were considered compatible with pulmonary thromboembolism. The patient was diagnosed with PE.

All examinations for the etiology of thromboembolism were performed. Evidence of thrombus was not observed in the lower extremity venous system. Reflux was observed at the left saphenofemoral junction. Factor $\vee$ Leiden, prothrombin
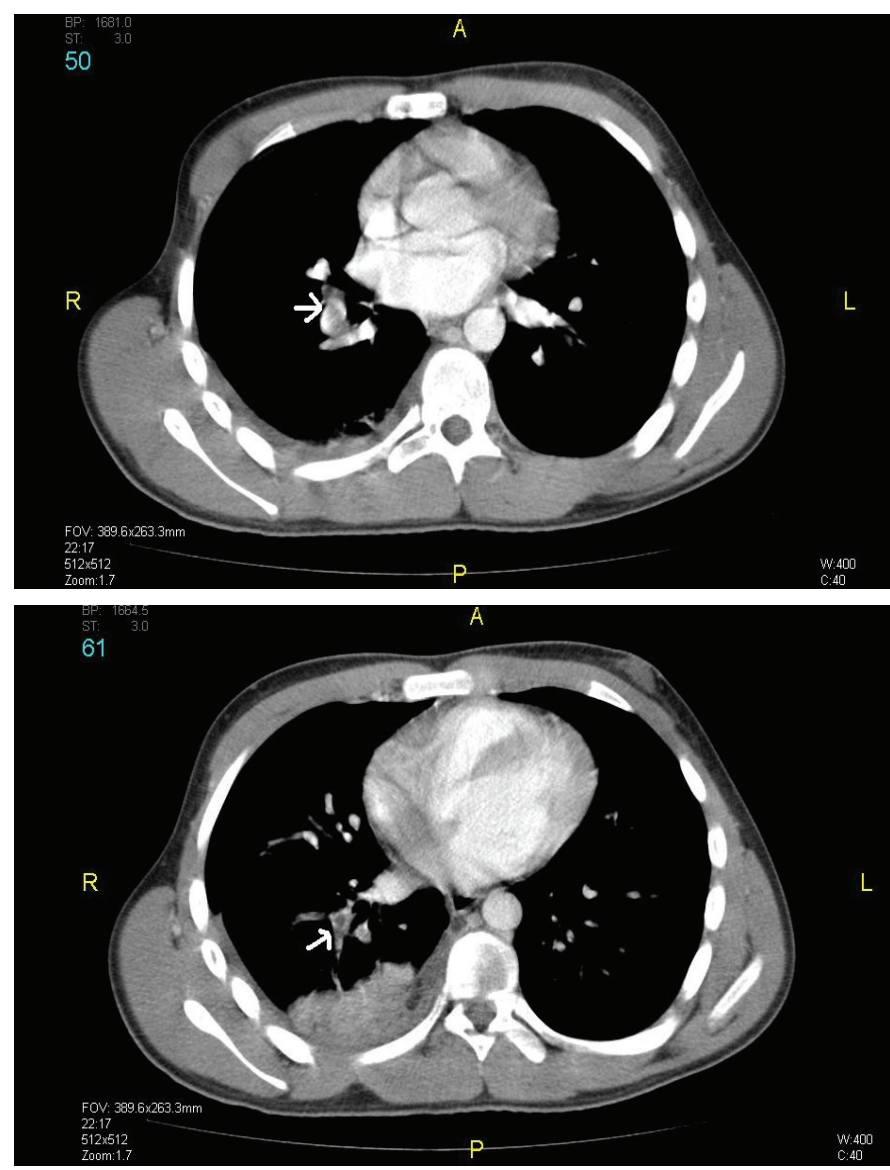

Figure 1. Central filling defect in the pulmonary artery branches and segmental branches of the lower lobe of the right lung 
20210, MTHFR gene mutations were not detected. Homocysteine was $15.1 \mu \mathrm{mol} / \mathrm{L}$ (5-14), lipoprotein (a) was $<0.0894 \mathrm{~g} / \mathrm{L}(0-0.74)$, antinuclear antibody was negative, anti dsDNA, anticardiolipin antibodies and lupus anticoagulant were negative. Antithrombin III was 61\% (83-128), factor VIII was $172.5 \%$ (50-150), factor IX was $119.5 \%$ (65-150), Von Willebrand factor was $180.6 \%$ (66.1-176.3), protein C was $140 \%$ (70-140), protein $S$ was $126.9 \%$ (63.5-149) and paroxysmal nocturnal hemoglobinuria panel was normal. The echocardiogram was normal.

Anticoagulant therapy was started as conventional heparinization at a rate of $20 \mathrm{U} / \mathrm{kg} / \mathrm{hr}$ after loading $50 \mathrm{U} /$ kg. Heparin doses were titrated with 4-hour coagulation parameters. Heparin infusion therapy was changed to lowmolecular-weight heparin (LMWH) treatment on the third day of admission. LMWH was set to an anti-factor Xa level starting at $1 \mathrm{mg} / \mathrm{kg} /$ dose 2 doses a day.

Treatment with risperidone, quetiapine and valproic acid for the patient, who was considered to have PE due to risperidone use, was discontinued. Two days after the discontinuation of medication, haloperidol drops were started due to tremor and aggressive behavior of the patient. Propranolol was added to the treatment due to continued tremor, insomnia and agitation.

Ampicillin/sulbactam (6 $\mathrm{gr} /$ day) was started because the patient had fever and infiltrations in the chest X-ray. The treatment was rounded to 14 days.

PE development was considered due to risperidone usage by the patient with normal thromboembolic etiology examination results. The patient was treated with anticoagulation therapy and discharged at the end of the $14^{\text {th }}$ day with recommendations.

\section{Discussion}

$\mathrm{PE}$ is a severe clinical picture that is rarely seen in children with approximately $30 \%$ of mortality rate. 1,4,9,10 PE may be responsible for sudden cardiac insufficiency, cyanosis, hypotension, syncope, sudden death and rhythm problems in children. ${ }^{1}$ The most common symptoms are dyspnea and chest pain. ${ }^{3,6,8}$ Our case applied to the hospital with chest and abdominal pain.

Various clinical and environmental factors are risk factors for PE. The most significant ones are hereditary thrombotic disorders such as; congenital heart diseases, infections, operation history, malignancy, renal diseases, trauma, immobilization, hypovolemia, smoking, chemotherapy (L-asparaginase), lupus erythematosus, hemoglobinopathies, central venous catheterization, factor $V$ Leiden mutation, hyperhomocysteinemia, protein $\mathrm{C}, \mathrm{S}$ and antithrombin deficiencies. In general, the majority of patients with thromboembolism have at least one underlying risk factor. $2,3,11$ Risperidone is an antipsychotic that antagonizes serotonin and dopamine receptors. ${ }^{6}$ Risperidone has a weak D2 receptor blockade and strong 5HT2A (5-Hydroxytryptamine) receptor blockade with its benzisoxazole complex. It has no anticholinergic effectiveness, antagonizes alpha adrenergic and histaminergic receptors. ${ }^{8}$ It is used in the treatment of both positive and negative symptoms of schizophrenia. ${ }^{6}$ Studies have shown that risperidone is a safe drug. The risk for extrapyramidal side effect increases at doses higher than $10 \mathrm{mg} /$ day. ${ }^{7}$ Side effects include insomnia, fatigue, agitation, anxiety, hypersalivation, sedation, orthostatic hypotension, weight gain, akathisia, nasal obstruction, difficulty in concentration, abdominal pain and hyperprolactinemia. ${ }^{8}$ Risperidone has been shown to cause pulmonary thromboembolism as a result of its use in elderly patients, especially in those with risk factors. ${ }^{6}$ It is thought that the binding of antipsychotic drugs to the $5 \mathrm{HT} 2$ receptor increases the amount of serotonin and this increase also causes platelet aggregation, thus raising the risk of thrombosis. ${ }^{6}$

It has been determined that platelet aggregation may be affected by drugs with high 5HT2A receptor affinity such as risperidone. ${ }^{9}$ PE is not a common and well-known side effect of risperidone in children. The cases in the literature are generally adult patients. Maly et al. ${ }^{9}$ reported olanzapine and venous thromboembolism developed in 4 cases aged between 37 and 54 years. In their first large case-controlled study, Zornberg and Jick ${ }^{10}$ showed that risperidone increased the risk of idiopathic thromboembolism by 7 times.

Although it reflects mostly adult patients, psychiatric diseases (bipolar disorder, schizophrenia, psychosis, mania, catatonia) cause cortisol and catecholamine levels in blood. This leads to the development of endothelial damage and psychiatric patients are prone to thromboembolic diseases. ${ }^{12}$

It has been shown that these drugs increase the risk of thromboembolism especially in patients over the age of 65 who use antipsychotics. ${ }^{10}$

One pediatric patient with risperidone-induced PTE has been reported so far. ${ }^{1}$ There are no cases in the literature, of adolescents developing pulmonary thromboembolism due to the use of risperidone without an underlying risk factor.

According to the literature, the risk of developing venous thromboembolism due to the use of antipsychotic drugs in the first 3 months is high. ${ }^{6}$ In our patient, the VTE developed after 2 months of drug use.

When PE is suspected, rapid initiation of anticoagulant therapy is of vital importance. ${ }^{1}$ Anticoagulant was started in line with our clinical experience. Tissue plasminogen 
activator should also be considered as treatment options in this patient. However, the aim of this article is not to offer treatment options for PE. In our case report, it is emphasized that psychological disorders and drugs used for these diseases may cause PE in childhood.

In conclusion, this is the first adolescent case of PE development due to risperidone use reported in the literature. Antipsychotic drugs, which are preferred due to their lowside-effect profiles, increase the risk of thromboembolism not only in elderly patients but also in young people. This case has been presented to draw attention to this rare side effect of the drug.

Finally, the first condition for the PE diagnosis of this lifethreatening condition is the suspicion of the pediatrician. Although it is mostly seen in adults, it should be kept in mind that patients with psychiatric problems may present with symptoms that are not typical.

\section{Ethics}

Informed Consent: Informed consent was given from patient's family.

Peer-review: Externally peer-reviewed.

\section{Authorship Contributions}

Surgical and Medical Practices: T.K., N.Ç., Concept: T.K., N.Ç., Design: N.Ç., E.A., Data Collection or Processing: T.K., Analysis or Interpretation: T.K., N.Ç., Literature Search: E.A., Writing: M.K.Y.

Conflict of Interest: No conflict of interest was declared by the authors.

Financial Disclosure: The authors declared that this study received no financial support.

\section{References}

1. Ronco R, Catalan J, Salgado C, Vogel A. Syncope: a rare presentation of massive pulmonary embolism in a previously healthy girl. Pediatr Emerg Care. 2010;26:287-9.

2. Andrew M, David M, Adams M, Ali K, Anderson R, et al. Venous thromboembolic complications (VTE) in children: first analyses of the Canadian Registry of VTE. Blood. 1994;83:1251-7.

3. Van Ommen $\mathrm{CH}$, Peters $\mathrm{M}$. Acute pulmonary embolism in childhood. Thromb Res. 2006;118:13-25.

4. Bergqvist $D$, Lindblad B. A 30-year survey of pulmonary embolism verified at autopsy: an analysis of 1274 surgical patients. Br J Surg. 1985:72:105-8

5. Buck JR, Connors RH, Coon WW, Weintraub WH, Wesley JR, et al. Pulmonary embolism in children. J Pediatr Surg. 1981;16:385-91.

6. Borras L, Eytan A, de Timary P, Constant E-L, Huguelet $\mathrm{P}$, et al. Pulmonary thromboembolism associated with olanzapine and risperidone. J Emerg Med. 2008;35:159-61.

7. Öncü F, Habib A, Ceylan ME, Ceylan N, Yazan B. Atypical neuroleptics. Düşünen Adam. 1998;11:21-9.

8. Van Kammen DP, Marder SR. Clozapine. In: Kaplan HI, Sadock BJ (eds). Comprehensive textbook of psychiatry. 6th ed. Baltimore:Williams and Wilkins;1995:1979-2022.

9. Maly R, Masopust J, Hosak L, Urban A. Four cases of venous thromboembolism associated with olanzapine. Psychiatry Clin Neurosci. 2009;63:116-8

10. Zornberg $\mathrm{GL}$, Jick $\mathrm{H}$. Antipsychotic drug use and risk of first-time idiopathic venous thromboembolism: a case-control study. Lancet. 2000:356:1219-23.

11. Van Ommen $\mathrm{CH}$, Heijboer $\mathrm{H}$, Büller $\mathrm{HR}$, Hirasing RA, Heijmans $\mathrm{HS}$, et al. Venous thromboembolism in childhood: a prospective twoyear registry in The Netherlands. J Pediatr. 2001;139:676-81.

12. Barnhorst A, Xiong G. Pulmonary Embolism in a Psychiatric Patient. Am J Psychiatr. 2014;171:1155-7. 